$\begin{array}{ll}\text { DE } & \begin{array}{l}\text { DE GRUYTER } \\ \text { OPEN }\end{array} \\ \substack{10.1515 / \text { cris-2015-0005 } \\ \text { OP }} & \end{array}$

\title{
SUSTAINABLE PROFIT
}

NATÁLIA KRÄTSMAR-ŠMOGROVIČOVÁ 
One of the earliest definitions of sustainable development was offered in the 1987 UN Bruntland Report (United Nations, 1987, p. 16): "... to ensure that it meets the needs of the present without compromising the ability of future generations to meet their own needs". In this respect, one can claim that sustainability reflects and entails certain responsibilities to others, shareholders and stakeholders, and the environment, both social and natural. In general, a company is seen as an artificial entity (Friedman, 1970), whose only responsibility is to maximise its profits and use shareholders funds in a legal and profitable way. However, companies have responsibility beyond making own profits (Schwartz and Saiia, 2012, p. 4), since their impact goes beyond simple market transactions. Profits should not be confused with power maximisation, as this might lead to the omission of ethical considerations and fair practices. This paper will argue that by embracing sustainable development as an ethical choice, a company satisfying certain environmental and social constraints can gain long-term benefits, even from a profitability point of view, meeting the shareholder imperative of maximising shareholder wealth. As a corollary, it will be shown that when dealing with strategy, innovation, and profit, a shift of mind-set on the part of businesses is required: to move from short-termism to long-termism.

On the one hand, following Lomborg (2001), it may be argued that there is no statistical evidence that the environment suffers as much as is often claimed. For example, there is no statistical evidence that the quality of air in London would be poorer, on the contrary it has improved, or that forest area has decreased (Lomborg, 2001, p. 10).

However, this does not mean that companies do not cause certain impacts (Schirone and Torkan, 2012). For instance, one can look at the BP accident in the Gulf of Mexico or the activities of tobacco companies. Beyond market transactions, companies use the environment, natural and social, to produce goods and services for profit. While doing so, they affect the environment. Companies affect the market economy, employees, local communities, and nature. Every company generates pollution, unnecessary waste, defects, stored materials, excessive packaging, and other hidden costs in products' life cycles (Porter and van der Linde, 1995, p. 122); these aspects harm business, since they are a sign of inefficiency and thus economic waste. This indicates that resources are allocated and used ineffectively (Porter and van der Linde, 1995, p. 122) and lack optimal distribution. These activities therefore distract from companies' internal and market economies, which impacts shareholder value creation, as operational performance, and hence maximisation of potential profits are harmed. Besides, the environment also impacts companies' competitiveness and production-related activities (Porter and Kramer, 2006, p. 83; Schirone and Torkan, 2012, p. 182). Safe products and labour conditions enable lower costs of accidents, allure customers, and strong regulations can protect companies' competitive advantage (Porter and Kramer, 2006, p. 83). For instance, Toyota production affects both the environment and the bottom line (Miel, 2011). Through its production and waste, Toyota affects not only the natural environment, but also the economic health of the company in the long-term through reduced efficiency (Porter and van der Linde, 1995; Miel, 2011). Toyota's sustainability reports resulted in USD 500,000 of annual savings. Eventually their hybrid technology also enabled them to reap competitive advantage, and eventually other companies had to licence this technology (Porter and Kramer, 2006, p. 88).

Unsustainable practices harm society. Consumers are the ones who bear the costs (Porter and van der Linde, 1995, p. 122) of recycling, pollution, unnecessary packaging, or waste energy, since these all add to the cost of production, reflected in prices and tax payments. They can also cause price differentials, which is unfair to society.

\section{The impact on nature, society, and economy raises ethical issues when companies fail to maximise utility through appropriate allocation of resources, effective production, and distribution.}


Utilitarianism promotes the utility principle, which emphasises the greatest happiness of the greatest number, as the foundation of morals (Fisher and Lovell, 2009, p. 129). Hence, it represents the policy stance that aims to improve aspects of life. The impact on the environment violates this principle, since it largely benefits only a small number, the producer, the company. Under the assumption that agents are fully rational and that the outcomes of actions are quantitatively measurable, Jeremy Bentham (Fisher and Lovell, 2009, p. 129) proposes a framework based on the possibility of calculating benefits and costs of specific sets of actions to define morality. This allows performing a hedonistic calculus (Fisher and Lovell, 2009, p. 129) based on outcomes in terms of pain and pleasure, the two masters under which humans live their lives. Profitability does increase pleasure for shareholders, but this does not imply there is no pain for others (Fisher and Lovell, 2009, p. 129). Pursuing sustainability is the good action to do, because the consequences benefit the greatest number and allow future generations to use resources in the same productive way, as people are able to now.

Cost-benefit analysis is a typical tool for evaluating actions in this context. It is advantageous because companies and shareholders often have misleading perceptions of costs. External and opportunity costs of sustainability as well as costs of addressing regulations are incurred through unsustainable practices (Porter and van der Linde,1995, p. 128). But, those long-term costs (Porter and van der Linde, 1995, p. 125), particularly related to the environment, can be minimised, as has been shown, since innovation can be pursued with low investments and short payback periods, and generate much greater savings. For example, Dow Chemical's (Porter and van der Linde, 1995, p. 126; Holliday, 2001), under pressure to comply with a new law, redesigned its production, which cost USD 240,000, but generated a savings of USD 2.4 million through the reuse of materials as raw inputs.

To justify sustainability to shareholders, cost-benefit analysis enables the measurement of all the benefits and costs associated with a particular action. Companies thus need to identify costs and benefits (Williams, 2008) associated with a particular action. Then, they can evaluate those costs and benefits with regard to time, discounting, and risk. Finally, it is possible to measure the overall costs and benefits and thus determine whether or not to pursue the action (Fisher and Lovell, 2009, p. 131).

However, cost-benefit analysis can be problematic in the complex environment, where not everything can be quantified (Fisher and Lovell, 2009, p. 131). It is therefore in companies' interests to develop a specific measure through suitable metrics that would allow the provision of evidence specific to companies' business, such as "shareholder value added per pound of production" (Holliday, 2001, p. 6). Such evidence can serve as justification through addressing shareholder value creation.

In addition to price differentials, ineffective production, waste, and pollution affect the distribution of benefits and lead to unfair differences in the quality of the environment, opportunities, and prices of other commodities people are exposed to. Successful businesses require a healthy society, since education, health care, and equal opportunities are fundamental for a productive workforce (Porter and Kramer, 2006, p. 83; Chouinard, Ellison and Ridgeway, 2011). Thus, from a strategic point of view, shareholder value is not maximised when the environment and the market suffer or when unequal opportunities result.

Rawls' general principle of justice (Rawls, 1999, p. 11) represents the principle stance and was developed on the basis of the original position where political, economic, and social systems can be contrasted and the principle of justice as fairness is defined in the veil of total ignorance. This ensures that no one is disadvantaged and no one is advantaged. In this position (Rawls, 1999, p. 11), agents are assumed to be rational and all fundamental agreements are fair. This is why Rawls considers justice as fairness, as the original position is fair to everyone, which conflicts with inequality and unsustainable practices. However, Rawls' original position is hypothetical and a certain degree of risk taking is needed. In such a position, Rawls (Fisher and Lovell, 2009, p. 117) argues that a rational person would choose the "maximin" strategy, when the right option is the one where the most disadvantaged are protected. The general principle is represented by two main principles of 
justice, equal liberties and the equality principle (Rawls, 1999, p. 53). The equality principle has two criteria (Rawls, 1999, p. 65), fair equality of opportunity and the difference principle. Therefore, Rawls recognises differences among people, but those possessing better qualities and attributes should not benefit at the expense of others (Fisher and Lovell, 2009, p. 118). Based on the principle of fair opportunities, one can derive a principle of responsibility. It is our own responsibility to ensure those fair opportunities. Collective responsibility and process can meet this need. Thus, also counting ourselves as members of the future society, the principle justifies sustainable development in the name of fairness and equal opportunities for the next generation. Furthermore, collaborations and collective processes improve impacts on the social and natural environments (Nidumolu et al., 2014). They also benefit shareholders, since collaborations can "create value for everyone" by avoiding future costs and improving business efficiency, innovation and productivity (Nidumolu et al., 2014).

Not only collaborations, but also individual practices promote strategic position through reputation. Negative publicity and consequent punishment from stakeholders for unethical, unsustainable behaviour (Trudel and Cotte, 2009; Nations Environment Programme, 2013) can limit long-term performance. Hence, sustainability is a strategic tool that drives positioning, which strengthens differentiation and competitive advantage (Kiernan, 2001; Hunt, 2003; Porter and Kramer, 2006; Trudel and Cotte, 2009; Schirone and Torkan, 2012), because as an intangible asset, sustainability is hard to imitate (Adams, Thornon and Sepehri, 2012 p. 3). Subsequently, sustainability can benefit companies, because those who embrace it can exploit the potential of marketing in the name of sustainable development, and thus attract talent, investors, and customers (Kiernan, 2001; Gore and Blood, 2007; Schirone and Torkan, 2012; Clark, Feiner and Viehs, 2014; United Nations Environment Programme, 2013). This can promote long-term value maximisation, through lower cost of capital, a pool of talented workforce, and the impact on share prices (Clark, Feiner and Viehs, 2014, p. 7). However, the reputation argument focuses only on the external audience and rarely on the strategic benefit (Porter and Kramer, 2006, p. 83). Unless sustainability is rooted in strategies and operations specific to the business, reputation cannot benefit companies in the long-term, as this limits the extent to which businesses can differentiate themselves. Even only partial sustainability, for example with one product or service, can yield similar benefits as full embracement (Trudel and Cotte, 2009), though such a strategy is not long-term, since it does not promote the company's innovation and competitiveness. Hence, sustainability should not be seen as a mean to mitigate immediate consequences, but to prevent them in the long-term; this why it should be rooted in companies' cores, which implies a sea change in strategy, not only adjustments (Porter and Kramer, 2006).

There are various indicators where companies' reputations are reflected, such as the Dow Jones Sustainability Index (Adams, Thornon and Sepehri, 2012 p. 11). Analysis reveals that sustainability does not have a significant impact on share price in the short run, but there is a potential long-term positive correlation. This is supported by the new report From Stockholders to Stakeholders (Clark, Feiner and Viehs, 2014), which shows a positive correlation between sustainability and share prices. Particularly, companies that scored poorly on the environmental element experienced low or a decline in share prices. An example is the BP incident, when share prices declined by $50 \%$ and have underperformed by $60 \%$ ever since; thus, the level of responsibility to the environment reflects in the performance and affects shareholders (Clark, Feiner and Viehs, 2014).

Consequently, one needs to regard sustainability as a long-term strategic tool, since short-termism limits opportunities and companies' capabilities (Repenning and Henderson, 2010; Adams, Thornton and Sepehri, 2012; Clark, Feiner and Viehs, 2014, PRI reference). Peter Senge (1990) emphasised the importance of individual learning for further development of an organisation. This does not imply learning as acquiring information, but rather a shift of mind from the static mind-set (Fisher and Lovell, 2009, p. 121). As a result, companies need a fundamental shift in their organisational structure or design (Meen and Keough, 1992, p. 66; Porter and Kramer, 2011). 
Such a shift requires transformational ethical leadership, leaders who define the change, take on responsibility, motivate and mobilise people (Rijal, 2010) through ethical principles and values. Managers also need to promote openness and creativity in order to support such behaviour (McGill, Slocum and Lei 1992, p. 14). This represents a shift from adaptive learning, which is short-term oriented and where people only react to stimuli in the environment (McGill, Slocum and Lei, 1992, p. 6), to long-term generative learning, where experiments and change are supported and learning occurs independently of the environment, which enhances innovation and efficiency (McGill, Slocum and Lei 1992). However, companies and shareholders are often risk averse (Durodié, 2004) and reserved towards change, since managers often have incomplete information about the costs and benefits (Porter and van der Linde,

1995, p. 127) and pressure on executives from financial markets focuses on short- term results (Clark, Feiner and Viehs, 2014, p. 9). Particularly the costs of implementing sustainability arouse scepticism. But these costs can be as much as half of what analysts estimate, as in the case of compliance with sulphur dioxide emissions (Porter and van der Linde, 1995, p. 129). Companies can use the cost-benefit analysis to justify sustainability and design their own metrics.

By pursuing sustainable development, companies can also make use of their power, which is often greater than that of governments, to deal with social, economical, and environmental issues (Gore and Blood, 2007; Fisher and Lovell, 2009, p. 301; Nidumolu et al., 2014). Companies are not often motivated to pursue sustainability unless there is an outside competitive pressure, or regulation forces them (Porter and van der Linde, 1995, p. 125). Additionally, a static mind-set pushes companies to think that sustainability comes with high costs. They do not consider the learning curve, long-term economic and competitive benefits, which makes them resistant towards compliance with regulations (Porter and van der Linde, 1995, p. 130). These attitudes limit their competitiveness, as they restrain innovation (Porter and van der Linde, 1995, p. 128). This emphasises the importance of the shift. However, not all regulations making companies comply with sustainable practices generate benefits. Regulations frequently discourage risk-taking and experiments, since governments tend to be inflexible in their enforcement (Porter and van der Linde, 1995, p. 129). Regulations should be designed to give companies freedom to solve their specific problems and issues, and thus support innovation. Companies should therefore use their power to help improve regulations in these ways (Porter and van der Linde, 1995, p. 129).

To conclude, sustainable development is not only ethical, it also supports long-term business growth. It has been shown that moving from the ethical policy to principle does not alter support for sustainable development. Utilitarianism supports thinking about future generations, seeking to ensure they are not left with less productive means. Justice as fairness allows future generations to have fair opportunities, as one has now. Moreover, sustainable development allows economic waste to be minimised, triggers innovation, and leads to better operational performance, which is essential for long-term competitive advantage. Thus, increased efficiency and ethical behaviour improves reputation, which, as one of the most recent studies has shown (Clark, Feiner and Viehs, 2014), has a positive impact on share prices. However, to avail themselves of those benefits, companies need to shift their static mind-sets and move from short- termism to long-termism. They need to think about resources that can be used to sustain their business. The shift needs to take place in the businesses' cores in order to exploit the long-term strategic potential (Porter and Kramer, 2011). Hence, meeting social and environmental needs enables companies to improve their performance and maximise long-term value creation for shareholders. 


\section{REFERENCES}

Adams, M., Thornton, B. and Sepehri, M. (2012) 'The impact of the pursuit of sustainability on the financial performance of the firm', Journal of Sustainability and Green Business, 1(April), pp. 1-14.

Brown, B. and Anthony, S.D. (2011) 'How PerG tripled its Innovation Success Rate', Harvard Business Review, 89(6), pp. 64-72. Chouinard, Y. Ellison, J. and Ridgeway, R. (2011) 'The Sustainable Economy', Harvard Business Review, 89(10), pp. 52-62.

Clark, G.L. Feiner, A. and Viehs, M. (2014) From the Stockholder to the Stakeholder. How Sustainability Can Drive Financial Outperformance. Available at: http://www.smithschool.ox.ac.uk/library/reports/SSEE_Arabesque_Paper_16Sept14.p df (Accessed: 18 November 2014).

Durodié, B. (2004) 'Book Reviews'. Review of The Timid Corporation - Why Business is Terrified of Taking Risk, by Benjamin Hunt. Risk Analysis: An International Journal, 24(1), pp. 301-304. doi: 10.1111/1539-6924.00284.

Fisher, C. and Lovell, A. (2009) Business Ethics and Values. Individual, Corporate and International Perspectives. 3rd edn. Harlow: Pearson Education Limited.

Friedman, M. (1970) 'The Social Responsibility of Business is to Increase Its Profits', The New York Times Magazine (September), pp. 122-6.

Gore, A. and Blood, D. (2007) 'Sustainability. It's a sound investment', Leadership Excellence, 24(8), pp. 3-4.

Holliday, C. (2001) 'Sustainable Growth, the DuPont Way' Harvard Business Review, 79(8), pp. 129-34.

Hunt, B. (2003) 'Self-regulation: Entrenching Caution', The Timid Corporation: Why Business is Terrified of Taking Risk. Chichester: John Wiley er Sons Ltd, pp. 45-81.

Kiernan, M.J. (2001) 'Eco-Value, Sustainability, and Shareholder Value: Driving Environmental Performance to the Bottom Line', Environmental quality management, 10(4), pp. 1-12. doi: 10.1002/tqem.1100.

Lomborg, B. (2001) The Skeptical Environmentalist: Measuring the Real State of the World. 2nd edn. Cambridge: Cambridge University Press.

McGill, E.M., Torkan, J.W.Jr and Lei, D. (1992) 'Management practices in learning', Organizational Dynamics, 21(1), pp. 4-17. doi: 10.1016/0090-2616(92)90082-X.

Meen, D.E. and Keough, M. (1992) 'Creating the Learning organization', McKinsey Quarterly, (1), pp. 58-78.

Miel, R. (2011) 'Production processes affect both environment, bottom line', Plastic News, 23(21), pp. 4.

Nidumolu, R., Ellison, J., Whalen, J. and Billman, E. (2014) 'The Collaboration Imperative', Harvard Business Review, 92(4), pp. 76-84.

Porter, M.E. and Kramer, M.R. (2006) 'Strategy e Society: The Link Between Competitive Advantage and Corporate Social Responsibility', Harvard Business Review, 84(12), pp. 78-92.

Porter, M.E. and Kramer, M.R. (2011) 'Creating Shared Value', Harvard Business Review, 89(1/2), pp. 62-77.

Porter, M. E. and van der Linde, C. (1995) 'Green and Competitive: Ending the Stalemate', Harvard Business Review, 73(5), pp. 120-134.

Rawls, J. (1999) A Theory of Justice. 2nd edn. Cambridge: Harvard University Press.

Repenning, N. P. and Henderson, R. M. (2010) 'Making the Numbers? "Short Termism" er The Puzzle of Only Occasional Disaster', HBS Working Paper (11-033).

Rijal, S. (2010) 'Leadership Style and Organizational Culture In Learning Organization: A Comparative Study', International Journal of Management e Information Systems, 14(5), pp. 119-128.

Schirone, D.A. and Torkan, G. (2012). 'New transport organization by IKEA: An example of social responsibility in corporate strategy', Advances in Management er Applied Economics, 2(3), pp. 181-193.

Schwartz, M.S. and Saiia, D. (2012) 'Should Firms Go 'Beyond Profits'? Milton Friedman versus Broad CSR', Business er Society Review, 117(1), pp. 1-31. doi: 10.1111/j.1467-8594.2011.00397.x.

Senge, P.M. (1990). The Fifth Discipline: The Art and Practice of the Learning Organisation. London: Century.

Trudel, R. and Cotte, J. (2009) 'Does It Pay to Be Good?', MIT Sloan Management Review, 50(2), pp. 61-68. 
United Nations (1987) Our Common Future. Available at: http://www.un- documents.net/our-common-future.pdf (Accessed: 20 November 2014).

United Nations Environment Programme (2013) PRINCIPLES FOR RESPONSIBLE INVESTMENT: An investor initiative in partnership with UNEP Finance Initiative and the UN Global Compact. Available at: http://www.unpri.org/viewer/?file=wpcontent/uploads/PRI_Brochure_2013.pdf (Accessed: 29 November 2014).

Williams, B. (2008) 'Methods explained: Cost-benefit analysis', Economic and Labour Market Review, 2(12), pp. 67-70. 